\title{
Neonatal Mortality in Two Tertiary Pediatric Hospitals in Baghdad (2012-2016)
}

\author{
Hasanein A. Jawad* \\ Eman A. Al-kaseer** \\ Jawad KA Al-Diwan**
}

\author{
MBChB \\ FIBMS \\ MSc, DCN, FIBMS, FFPH
}

\begin{abstract}
:
Fac Med Baghdad between conflict and neonatal mortality in Baghdad, Iraq.

Background: Many studies have linked the prevalence of violence and conflicts to the increasing number of neonatal mortality rate (NMR). This study was conducted to clarify the relationship 2017; Vol.59, No.4 Objective: Throw a light on the impact of conflicts on neonatal mortality in Iraq.

Received: Oct 2017 Methods: This cross-sectional study was carried out in two hospitals in Baghdad that were chosen Accepted: Dec.2017 randomly. All deceased newborns in neonatal intensive care units from January 2012 to December 2016 in the mentioned hospitals were included in this study.

Results: The admissions were increased during the period of the study by 1.3 times. There was a decrease in admission by 0.9 in 2016 than 2015 . There was an increase in NMR during the period of the study by 1.4 times, from 60/1000 in 2012 to $85 / 1000$ in 2016 .

Conclusions: There has been an observed increase in neonatal mortality in Iraq due to the impact of conflicts that have led to deterioration in the neonatal health status.

Key words: neonatal mortality, Baghdad, Iraq, conflicts.
\end{abstract}

\section{Introduction:}

Neonatal Mortality (NM) is a key outcome indicator that used to assess and evaluate the development of maternal and neonatal health services in the community.1 Neonatal mortality includes all infants dying during the period from after birth to the first 28 days of life. 2 Neonatal morbidity and mortality reflect a country's socioeconomic status, and the efficiency and effectiveness of health care services.3-6

Iraq has been suffering from wars, economics hardship, internal displacements since 1980s. This situation leads to Iraq being one of the highest level of NM in the eastern Mediterranean region.7-9

War-affected populations suffer from poor maternal health, infant mortality and bad birth outcomes during the active stages of conflict.10,11 War has an adverse impact on the health infrastructure.12,13

This study aimed to throw a light on the impact of conflicts on health of newborns in Baghdad, Iraq.

\section{Materials and methods:}

This retrospective analytical cross-sectional study was carried out over five years period (2012-2016) in the Children's Welfare Teaching (CWT) hospital and Al-Kadhimiya children (KC) hospital, that were chosen randomly. All cases records of deceased

* Al-Elwia Maternity Teaching Hospital

E-mail: hsnen2010@gmail.com

**Dept. of Community Medicine, College of Medicine, University of Baghdad. newborns in neonatal intensive care units (NICUs) from January 2012 to December 2016 in the mentioned hospitals were included in this study.

Neonatal mortality rate (NMR) was calculated during the studied period and between the hospitals. $\mathrm{Z}$ test was used to measure the difference of NMR. $\mathrm{P}$ value $<0.05$ was considered to be statistically significant.

\section{Results:}

Total admissions in NICUs were 21,803. In CWT hospital, there were 12,298 neonatal admissions, 777 (6.3\%) neonatal deaths, and in $\mathrm{KC}$ hospital out of 9,505 total neonatal admissions, 517 (5.4\%) deaths. The admissions increased during this study by 1.3 times, there was a decrease in admission by 0.9 in 2016 than 2015 . The NMR increase by 1.4 times during the studied period (Table 1). Total NMR in 2012 was $60 / 1000$ and in 2016 was $85 / 1000$ ( $\mathrm{Z}$ test= 2.1558 , p value $=0.03)$. Death of newborns was increased during this study (1.8 times) with increase the numbers of graduated pediatric specialists (4.3 times) as shown in figure 1 . There was no significant difference in NMR between the mentioned hospitals for each year of the study as shown in Table 1 . 
Table 1 NMR and Total Number of Admissions and Deaths

\begin{tabular}{|c|c|c|c|c|c|c|c|c|}
\hline \multirow[b]{2}{*}{ Year } & \multicolumn{3}{|c|}{ CWT Hospital } & \multicolumn{3}{|l|}{ KC Hospital } & \multicolumn{2}{|c|}{ Statistical test } \\
\hline & Admissions & Deaths & NMR & Admissions & Deaths & NMR & $\mathrm{Z}$ test & $\mathrm{P}$ value \\
\hline 2012 & 1995 & 130 & 65 & 1611 & 88 & 55 & 0.942 & 0.35 \\
\hline 2013 & 2251 & 95 & 42 & 1691 & 76 & 45 & 0.329 & 0.74 \\
\hline 2014 & 2683 & 138 & 51 & 2060 & 83 & 40 & 1.180 & 0.24 \\
\hline 2015 & 2820 & 175 & 62 & 2152 & 124 & 58 & 0.377 & 0.70 \\
\hline 2016 & 2549 & 239 & 94 & 1991 & 146 & 73 & 1.697 & 0.09 \\
\hline Total & 12298 & 777 & 63 & 9505 & 517 & 54 & 0.858 & 0.39 \\
\hline
\end{tabular}
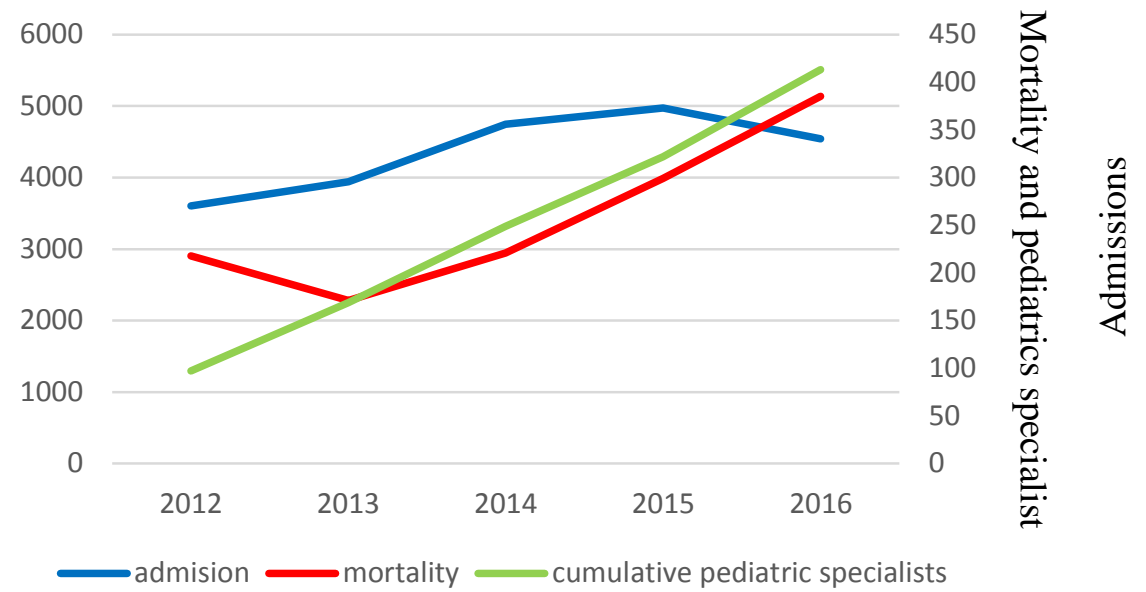

Figure 1 Distribution of Total Number of Admissions and Death

\section{Discussion:}

This study revealed an increase in the admission of neonates in both studied hospitals. This finding reflects the increases in the prevalence of risk factors for abnormality among newborns which in turn lead to admission. The increase in the prevalence of risk factors might be attributed to conflicts. Several articles documented the effect of conflicts on neonatal mortality.12,14-17 Publishing in Iraq documented the increase in the prevalence of prematurity and low birth weight during the years of conflicts.18,19 Conflicts affect populations in several ways, to enumerate some of them; the natural growth rate and increased fertility, marriages, teenage pregnancies, hospital birth rate, demands for admissions, and increased total childbirth based on socioeconomic and cultural influences.20-23 This phenomenon of natural increase and population growth might be explained by redistribution of wealth after 2003.24,25

There was a slight decrease of newborns admission in 2016 than the previous year by 0.9 . This finding might be explained by change in health policy (charging for admission was applied in 2016).26,27 The frequency of neonatal death from 2012 to 2016 was increased by 1.8 time. This increase might be attributed to increased burden on health services in
Baghdad by wars, economics sanctions, internally displaced persons and widespread violence. 28

This study showed that the NMR continued to increase during the studied period, that reflects the deterioration of health system in Iraq, which has been affecting by conflicts. Conflicts affect training of physicians, even in postgraduate studies. It also affects essential medicines and other vital substances, which in turn leads to poor health services. 29,30

\section{Conclusion:}

Conflicts in Iraq have led to an observed increase in neonatal mortality rate, reflecting the deterioration in the maternal and child health care services during the studied period.

\section{Authors Contribution:}

Hasanein A. Jawad: data collector and writer of original draft.

Eman A. Al-kaseer: statically analyzer.

Jawad KA Al-Diwan: supervisor, discussing the results. 


\section{References:}

1. Yu YH. Victor Global, regional and national perinatal and neonatal mortality. J Perinal med 2003; 31:376-9.

2. Clarence $W$ and Gowen Jr. Fetal and Neonatal Medicine: Marcdante KJ, Kliegman RM in Nelson Essentials of Pediatrics 7 th ed. Philadelphia, Elsevier Saunders;2015. P. 187.

3. Omoigberale AI, Sadoh WE, Nwan eri DU. A 4year review of neonatal outcome at the University of Benin Teaching Hospital, Benin City. Niger J Clin Pract. 2010; 13: 321-5.

4. Sharma $V$, Katz J, Mullany LC, Khatry SK, LeClerq SC, Shrestha SR, et al. Young maternal age and the risk of neonatal mortality in rural Nepal. Arch Pediatr Adolesc Med. 2008 Sep;162(9):828-35.

5. Kiely JL, Paneth N, Susser M. An assessment of the effects of maternal age and parity in different components of perinatal mortality. Am J Epidemiol. 1986 Mar;123(3):444-54.

6. Galor O. The Demographic Transition: Causes and Consequences. Cliometrica (Berl). 2012 Jan;6(1):1-28.

7. Abdulghani S, Sirhan YT, Lawas AK. Perinatal and neonatal mortality in Fallujah General Hospital, Fallujah City, Anbar Province, west of Iraq. Health J. 2012;4(9): 597-600.

8. AL-Ani ZR, AL-Hiali SJ. And AL-Farragi HH; Secular trend of infant mortality rate during wars and sanctions in Western Iraq, Saudi Med J. 2011 Dec;32(12):1267-73.

9. Rubin M. Sanctions on Iraq: A Valid AntiAmerican Grievance? Middle East Review of International Affairs. 2001 Dec.;5(4):100-15.

10. Isser D, Auweraert P. Land, property, and the challenge of return for Iraq's displaced. United states institute of peace. 2009 April. Available from: https://www.usip.org/sites/default/files/resources/1.p df. (accessed on 2017 Sept 24).

11. Lassi Z, Aftab W, Ariff S, et al. Impact of service provision platforms on maternal and newborn health in conflict areas and their acceptability in Pakistan: a systematic review. Conflict and Health. 2015;9(25). Doi: https://doi.org/10.1186/s13031015-0054-5.

12. Lindskog EE. The effect of war on infant mortality in the Democratic Republic of Congo. BMC Public Health. 2016 Oct 6;16(1):1059.

13. Fatusić Z, Kurjak A, Grgić G, Tulumović A. The influence of the war on perinatal and maternal mortality in Bosnia and Herzegovina. J Matern Fetal Neonatal Med. 2005 Oct;18(4):259-63.

14. Ali MM, Shah IH. Sanctions and childhood mortality in Iraq. Lancet. 2000 May 27;355(9218):1851-7.

15. O'Hare BA, Southall DP. First do no harm: the impact of recent armed conflict on maternal and child health in Sub-Saharan Africa. J R Soc Med. 2007 Dec;100(12):564-70.

16. van den Berg MM, Madi HH, Khader A, Hababeh M, Zeidan W, Wesley H. Increasing
Neonatal Mortality among Palestine Refugees in the Gaza Strip. PLoS One. 2015 Aug 4;10(8): e0135092. doi: 10.1371/journal.pone.0135092.

17. Macassa $G$, Ghilagaber $G$, Bernhardt $E$, Burström B. Trends in infant and child mortality in Mozambique during and after a period of conflict. Public Health. 2003 Jul;117(4):221-7.

18. Darweesh A, Al-Kaseer E. Low Birth Weight in Post-Conflict Baghdad, Iraq. IJSR. 2015;4(6):278990.

19. Abdul Latif BI, Al-Diwan JK, Al-Hadithi TS, AlHadi AH. Low birth weight and prematurity in the neonatal unit of a maternity and pediatrics hospital in Iraq. J Trop Pediatr. 2006;52(2):148-150.

20. Central Intelligence Agency. Intelligence \& Analysis - Products. Retrieved 2010 Oct. 23. The annual World Factbook is a comprehensive compendium of profiles on more than 260 countries and other entities. (Archived by Web: https://www.webcitation.org/5th2wiatu.

21. Nargund G. Declining birth rate in Developed Countries: A radical policy re-think is required. Facts Views Vis Obgyn. 2009;1(3):191-3.

22. Adhikari R. Demographic, socio-economic, and cultural factors affecting fertility differentials in Nepal. BMC Pregnancy Childbirth. 2010 Apr 28; 10:19. Doi: 10.1186/1471-2393-10-19.

23. Kumar GA, Dandona R, Chaman P, Singh $P$, Dandona L. A population-based study of neonatal mortality and maternal care utilization in the Indian state of Bihar. BMC Pregnancy Childbirth. 2014 Oct 17; 14:357. Doi: 10.1186/1471-2393-14-357.

24. Parker N. The Iraq We Left Behind: Welcome to the World's Next Failed State. Foreign Affairs. 2012 March April; 91(2): 94-110.

25. Cetorelli V, Shabila N. Expansion of health facilities in Iraq a decade after the US-led invasion, 2003-2012. Conflict and Health. 2014;8(16). Doi: 10.1186/1752-1505-8-16. Ecollection 2014.

26. Shukr MS. In a conversation with Director of Financial Planning. Iraqi Ministry of Health. Personal communication. 2017 May 7.

27. Ministry of health (MOH). Iraq. Annual Statistical Report (AR), 2016.

28. Lafta R, Aflouk NA, Dhiaa S, Lyles E, Burnham $G$. Needs of internally displaced women and children in Baghdad, Karbala, and Kirkuk, Iraq. Plos Currents. 2016;8(Disasters). Available from, DOI:

http://dx.doi.org/10.1371/currents.dis.fefclfc62c02e caedec2c25910442828.

29. World Health Organization. Violence threatens health in Iraq. Media Centre. Available from: http://www.who.int/mediacentre/news/releases/2007 /pr15/en.

30. Hicks MH, Dardagan H, Guerrero Serdán G, Bagnall PM, Sloboda JA, Spagat M. Violent Deaths of Iraqi Civilians, 2003-2008: Analysis by Perpetrator, Weapon, Time, and Location. Plos Med. 2011 Feb 15;8(2): e1000415. Doi: https://doi.org/10.1371/journal.pmed.1000415. 